\title{
Economic assessment of managing processionary moth in pine forests: A case-study in Portugal
}

\author{
Paola Gatto ${ }^{\mathrm{a}, *}$, Alessia Zocca ${ }^{\mathrm{b}}$, Andrea Battisti ${ }^{\mathrm{b}}$, Maria João Barrento ${ }^{\mathrm{c}}$, \\ Manuela Branco ${ }^{\mathrm{d}}$, Maria Rosa Paiva ${ }^{\mathrm{c}}$ \\ ${ }^{a}$ Department of Land and Agro-Forestry Systems, University of Padova, Agripolis, Viale dell' Università, 16, 35020 Legnaro, PD, Italy \\ ${ }^{\mathrm{b}}$ Department of Environmental Agronomy - Entomology, University of Padova, Agripolis, Viale dell Università, 16, 35020 Legnaro, PD, Italy \\ ${ }^{\mathrm{c}}$ Department of Environmental Sciences and Engineering, FCT, New University of Lisbon, Portugal \\ ${ }^{\mathrm{d}}$ Department of Forest Engineering, ISA, Technical University of Lisbon, Portugal
}

Received 17 December 2005; received in revised form 13 September 2007; accepted 3 January 2008

Available online 11 March 2008

\begin{abstract}
This paper assesses the private and social profitability of current strategies for managing processionary moth (Thaumetopoea pityocampa) in Portuguese pine forests, looking at economic and environmental costs and benefits. Costs include the expenses for forest treatment and the social costs of threats to human health (dermatitis amongst others); benefits are assessed in terms of both revenue and social benefits such as carbon fixation and recreation. The evaluation was done using Cost Benefit Analysis (CBA) as an analytical framework. While this tool is currently applied to forest and environmental assessment and specific applications to pest management strategies are to be found in agricultural economics, rather few attempts have been made in the field of forest pest management. In order to assess and compare with-without options, a case-study was analysed for the Setúbal Peninsula, south of Lisbon, an area where extensive stands of maritime pine (Pinus pinaster) grow. The exercise has shown that CBA can be a valuable tool for assessing the economic and social profitability of pest management. The results demonstrate that the loss of revenues in the no-management option is not sufficient to make pest management profitable for private forest owners in the shortterm. Conversely, a social profit is gained as pest management minimizes health risks for humans and avoids possible recreational losses.

(C) 2008 Elsevier Ltd. All rights reserved.
\end{abstract}

Keywords: Pest management; Pine processionary moth; Cost Benefit Analysis; Thaumetopoea pityocampa; Pinus

\section{Introduction}

Forest pests have considerable impact on the value and functionality of forest ecosystems, both directly (e.g. timber losses) and indirectly, as they may compromise the stand in relation to soil conservation, aesthetic values and avalanche protection. Defoliating insects can also cause tree death, thus reducing the vital functions of the forest and its scenic value. It has often been debated whether or not to adopt control measures against forest insect pests (Wainhouse, 2005). As forest insects are associated with tree decline and forest succession, forest managers and ecologists have put forward arguments

\footnotetext{
* Corresponding author. Tel.: +39049 8272719; fax: +390498272772.

E-mail address: paola.gatto@unipd.it (P. Gatto).
}

both for and against insect pest control. These include tree growth reduction (Larsson, 1983), aesthetic landscape alteration (Mattson et al., 1996), fragile ecosystem disturbance (Simberloff, 2001) and negative human consequences (Vega et al., 2000).

The winter pine processionary moth, Thaumetopoea pityocampa, has been at the centre of such discussions in Mediterranean countries (Masutti and Battisti, 1990), because it causes heavy defoliations to pine and cedar forests, and poses serious threats to human health, as the irritating hairs released by the larvae can cause both occupational and nonoccupational contact dermatitis (Fuentes Aparicio et al., 2004; Vega et al., 2004). In addition, the pest is very visible to the public due to its large silk nests in the tree canopy, where the larvae spend the winter months. Pest control is 
thus a necessity, and different approaches have been used, including mechanical, chemical and biological methods (Masutti and Battisti, 1990). Management of the processionary moth is now largely based on the use of Bacillus thuringiensis kurstaki (Btk) preparations, which have proved successful in preventing the pest multiplying, with limited environmental effects (Demolin and Martin, 1998).

Although effectiveness on the pest population has now been verified, few economic analyses have tested the profitability of using such control methods. This is an important issue for the private forest owner but also for society as a whole, since moth attacks can result in the loss of environmental functions of pine forests, therefore in hidden social costs.

This research attempts to fill this gap by running a cost/ benefit assessment of current strategies for managing processionary moth. The objectives of this work are twofold. Firstly, the paper aims to outline a possible framework for bioeconomic analyses of current and new pest management strategies within a broader social context than that attempted so far. The second objective of the work is to attempt an assessment of social profitability of current forest pest control methods in a specific case-study area, i.e. the Setúbal Peninsula, Portugal.

This information should prove highly useful in the formulation of forest policies, as it contributes towards the definition of financial tools and market-based actions to increase pest management profitability for the processionary moth, taking into account the interests of both the private and public sectors.

\section{The study area}

Portugal is a country where the majority of forests are privately owned (Carvalho Mendes, 2005). Pines represent about one-third of the forest area. It is estimated that as much as $70-80 \%$ of these stands have primarily a productive function (Forest Protection Department, personal communication). Protection of dunes from wind erosion, landscape improvement and recreation are also important - although sometimes implicit - secondary functions of these pine forests.

The Peninsula of Setúbal is located in the Estremadura Province, south of Lisbon. It has a total area of about 158,000 ha, of which $30 \%$ is farmland and 32\% forests, mainly pines. At the end of the 19th century, uncultivated sandy-loam soils dominated this land and vineyards provided the most widespread crop. In the early 20th century, given the need for timber and related processing industries, a major government afforestation plan - mainly with Pinus pinaster rapidly increased the forested area. This has resulted in extensive pine plantations the Setúbal area, most of which are privately owned and supply timber sold on the local market. Today, the economy of the area consists of forestry, together with fishing, mining industries and wine production. Tourism is also a relevant source of income: most visitors come in the spring and summer, spending time picnicking, hiking and biking in the woods.

The winter pine processionary moth attacks the whole area where $P$. pinaster grows. As management of pine stands is not mandatory, the decision to control infestations is up to the plantation owner and as little control is done as producers believe that the costs outweigh the benefits. This paper will determine if plantation owners are operating rationally and the social costs of such inaction. The control strategies available to the producers are mechanical measures that consist of placing insecticide-impregnated adhesive bands around pine trunks to capture caterpillars, or cutting and burning the nests, both methods being on a very small scale. Aerial applications of biological insecticides, mainly Diflubenzuron and Btk, are mostly used for larger areas, often under the supervision of the local Association of Forest Owners, and they usually concentrate on younger age-classes that are the most prone to the attack.

\section{Materials and methods}

In Mediterranean countries like Portugal, pine forests (mainly $P$. pinaster and Pinus pinea) are a valuable economic and environmental asset. They supply wood products, shelter wildlife, provide recreational opportunities and are an essential feature of the landscape. Mediterranean pines are pioneer species that can grow on steep slopes and poor soils, thus preventing soil erosion and stabilizing coastal dunes. In addition, pine stands represent a significant carbon sink.

This wide range of public services and externalities can be partially or totally lost when the ecosystem equilibrium is threatened by the processionary moth. Thus, full accounting of pest management costs and benefits can help policy-makers to assess its profitability in a comprehensive approach that considers both the private and social perspectives.

A literature survey on the economic aspects of forest pest management leads to the conclusion that this type of study, although important for forest and landscape managers, is not common. Conversely, the economic evaluation of pest management has been explored more frequently in the farming sector: examples can be found in Cornejo (1998), who analysed pest management in viticulture and Bangsund et al. (1999), who assessed the economic impact of weed control. Fleischer et al. (1999) provided guidelines for attempting an aggregated economic evaluation of pest management in agricultural crops. Mullen et al. (1997), Cuyno et al. (2001) and Brethour and Weersink (2001) provided estimates of the environmental benefits from reducing pesticide use in agriculture, while Saphores and Shogren (2005) discussed optimal control of exotic pests and the costs/benefits of collecting related bioeconomic data. Other recently published works on the subject have addressed other contexts, or focussed on specific aspects, like Jetter and Paine's (2003), which dealt with pest control in urban areas. Although these researches all contribute towards the scope of this work, few empirical applications have attempted to estimate the aggregate environmental effects of pest management in forest ecosystems.

As some of the benefits considered in this study are nonmarket, we believe that Cost Benefit Analysis (CBA) can be the appropriate methodology to approach the problem. CBA is a consolidated tool for the valuation of investments in 
forestry, with a history of over 30 years of applications following the works of Little and Mirrlees (1974) and Gregersen and Contreras (1979). The operational CBA framework used in this paper is the one proposed by Cesaro et al. (1998). Pointing out the shortcomings of the traditional distinction between financial and economic analyses, these authors designed a codified step-wise procedure for including off-site and non-market environmental effects in CBA.

The basic idea of this procedure is to progressively integrate environmental values components in the CBA. Five levels of costs and benefits are identified, including externalities and distributional effects, each corresponding to a step forward towards the full value of natural resources, as well as a more reliable approximation of the 'true' social costs and benefits, i.e. the welfare gain of the investment. These steps are briefly described as follows:

1. Financial Analysis (FA): only monetary flows of expenditures and revenues are taken into account; prices are those observed on the market and market profit is the only objective. For the purposes of our study, items in this step include timber revenues from clear-fellings and management costs, comprising fixed annual costs (e.g. surveillance) as well as variable costs, i.e. replanting immediately after final felling, understorey removal and stand cleaning and pruning undertaken within 15 years of planting. Pest management costs are for aerial applications of Btk, paid for by the forest owners and carried out by the Association of Forest Owners of Setúbal peninsula using contractors. The cost of the service includes equipment, labour and purchases. The forest landowner has no need for upfront fixed investments.

2. Conventional Economic Analysis (CEA): following CBA procedures, market prices of costs and benefits are converted into shadow prices by adjusting them through conversion factors to reflect the true value of resources, therefore eliminating distortions, market failures and transfer payments. Besides correcting for taxes and subsidies, if any, in this step we have included an item which takes into account permanent depletion of forest capital for the landowner in the case of moth attacks (Merlo and Jöbstl, 1999). This is a hidden variation in capital asset accounted for in terms of the annuity of the capitalised land value.

3. Extended Economic Analysis 1 (EEAl): off-site market effects are taken into account in this step, namely those external to the pine forest areas but still internal to the market; economic valuation techniques applied in this step can be based on indirect market effects; items considered include benefits as well as possible off-site damages. The point we wish to make is that pest management practiced by the forest owner in order to maintain forest productivity can also increase public welfare by producing social benefits or avoiding social costs. In this case-study we have identified one off-site market benefit, i.e. carbon sequestration, and one offsite cost, i.e. the risk of dermatitis when visitors come into contact with the larvae. Valuation for carbon sequestration refers to the present carbon market situation under the Kyoto Protocol see ${ }^{1}$.

4. Extended Economic Analysis 2 (EEA2): effects external to the market - i.e. intangibles, externalities, public goods/bads, on-site and off-site - enter the CBA in this step. This is the most challenging step, requiring the estimation of non-market values, in our case-study represented by the recreational value of the pine forests for visitors who use the pine forests in Setùbal for hiking, biking and picnicking. It accrues to society as a whole and not to the individual forest owner, so contributes to the increase of total social welfare. Dealing with externalities, the studies mentioned above (i.e. Mullen et al., 1997; Cuyno et al., 2001; Brethour and Weersink, 2001 and Jetter and Paine, 2003) used a Contingent Valuation (CV) survey to elicit consumers' willingness to pay for environmental benefits deriving from the application of pest management schemes. We agree with these authors that $\mathrm{CV}$ is the appropriate methodology in this context, also because of its flexibility in being able to evaluate a wide range of environmental benefits (Cuyno et al., 2001), including recreational values. ${ }^{2}$ However, running a complete CV survey is outside the scope of this paper, one of its aims being to explore the pros and cons of a comprehensive CBA framework rather than concentrating on methods for evaluating externalities. We have thus chosen to rely on Benefit Transfer techniques, i.e. the use of values taken from previous studies adjusted to the context being examined. Hanley et al. (2006) have recently suggested that Benefit Transfer techniques can be profitably used in policy analysis instead of ad hoc $\mathrm{CV}$ surveys, on the grounds that the latter are "extensive and time-consuming' and that the level of accuracy required by policy-makers, especially when prioritising or filtering alternatives needs not be the same as that required in academic work.

5. Socio-Economic Analysis (SEA): in this final step, costs and benefits are assigned to the various social groups and weighted according to their specific utilities; this is a rather controversial step both from the theoretical and practical points of view, being a way of attempting a socially differentiated analysis of the gains and losses that could be done at each step of the CBA. This last step has been excluded from this study, since a differentiation of the various groups of stakeholders on which costs

\footnotetext{
${ }^{1}$ In February 2005, the entry in force of the Kyoto Protocol, with its regulatory framework, has created and consolidated the market for carbon quotas, through which private and public institutions can buy emission reductions from projects involving greenhouse gases sequestration (e.g. forestry) or emission allowances under existing trade schemes. The market value unit is expressed by the price of 1 MT of carbon dioxide equivalent $\left(\mathrm{tCO}_{2} \mathrm{e}\right)$ (IETA, 2005).

2 In line with the existing environmental economics literature (for a complete discussion see, e.g. Bateman and Willis, 1999), these works also point out that the method is to some extent controversial, but also that appropriate actions exist in order to minimise biases.
} 
and benefits of pest management may fall is not possible, and probably not even meaningful.

Consequently, only FA, CEA, EEA1 and EEA2 will be done. In line with what was suggested by Lutz and Munasinghe (1994), the main idea underlying our work is not to provide finely tuned numbers (either cash-flows or Net Present Values, NPVs), but rather to identify which costs and benefits should be taken into account in this type of CBA and assign comparative orders of magnitude to their values.

\section{Defining scenarios}

The main challenge in developing this work was to identify and build plausible scenarios - following established CBA procedures - through which to assess the comparative profitability of managing processionary moth (i.e. the with situation) versus an alternative option of no-management (i.e. the without situation). The with scenario encompasses treatment costs as well as private and public benefits linked to conservation of the pine forest ecosystem; conversely, the without scenario portrays a condition where the pest attack in the absence of management causes decreased timber yields, loss of ecological functions and therefore private and public costs.

The CBA has been applied to 11,420 ha, which is the total land area covered by $P$. pinaster forest in the Setùbal Peninsula. Reference to the total area - instead of individual private forest estates - is consistent with the aggregated CBA approach described in Section 3, since the social benefits and costs only occur at this scale. The age-class distribution of the forest area of $P$. pinaster at year 0 of our analysis is reported in Table 1 . This has been assumed proportionally equal to that observed in the wider area of Lisbon and Vale do Tejo Region. The table shows that in the case-study area some stands are already mature and ready for felling, whereas others are at the start of the rotation. Mid age-classes (from 20 to 50 years) are less common. The age-class distribution is also important in relation to the processionary moth, as this pest prefers to attack trees aged less than 20 years.

The time-lapse over which the analysis is carried out is the average length of one forest rotation, i.e. 45 years. Cost and

Table 1

Distribution by age-class of Pinus pinaster managed forest area in the Setúbal Peninsula, Portugal

\begin{tabular}{lc}
\hline Age-classes (years) & Area (hectares) \\
\hline$<10$ & 2079 \\
$10-20$ & 1559 \\
$20-30$ & 520 \\
$30-40$ & 508 \\
$40-50$ & 520 \\
$50-60$ & 3118 \\
Irregular $^{\mathrm{a}}$ & 3118 \\
Total area & 11,420 \\
\hline
\end{tabular}

${ }^{\text {a }}$ Includes trees of different ages. The area falling under the 'Irregular' ageclass has been assumed as improductive and not attacked by the pine moth. revenue distribution is uneven during the rotation because of the different ages of the pine stands at the beginning of the analysis. However, the with and without scenarios follow similar patterns. The main difference is that pine moth treatment costs are included only in the with scenario. Only stands from 0 to 20 years of age are treated, where the damage caused by the processionary moth is greater and has more serious effects on tree growth.

Details of the two scenarios are reported in Table 2, following the steps proposed in Section 3. It should be taken into account that treating against processionary moth does not always result in a reduction of the area attacked, as the main reason for treating areas frequented by tourists is to keep the insect population level beneath the human tolerance threshold, i.e. a mean density of 0.5 winter nests/tree (Battisti, unpublished data).

In defining the scenarios, the first and one of the most difficult steps was to evaluate the impacts of the compared alternatives over the life-cycle of the investment. There are very few data available on the long-term consequences of pest attacks on forest trees. Entomological research concentrates on nest density and insect activity in terms of feeding days, which in turn allows defoliation rates and intensity of attack to be estimated. However, due to the long time-span over which the attack will produce consequences, it is difficult to quantify its impact on tree growth and productivity, forest density and therefore performance of related ecosystem functions such as carbon sequestration or recreation, which are intimately linked to forest characteristics.

This issue was tackled in France in the 1970s and 80s. According to Bouchon and Toth (1971), who studied an attack of the processionary moth on a black pine forest on Mont Ventoux (south-western France), the resulting timber losses could be as high as $20-45 \%$. However, this research did not distinguish between the effects of processionary moth and that of other factors that may have affected tree growth in the same period, such as climate variations, or other pests. Similar data were published by Lemoine (1977) and, more recently, by Laurent-Hervouët (1986) and Hódar et al. (2003), who measured timber losses reaching $31-35 \%$ of potential (i.e. not attacked) growing stock in the case of heavy attacks. ${ }^{3}$ Lower growth reduction was observed on Pinus brutia in Turkey (Carus, 2004; Kanat et al., 2005). Based on the estimates of these three studies, we have cautiously assumed that the effects of processionary moth on timber yield could be around $20 \%$ of the growing stock in the first 20 years of age.

For the Financial Analysis (FA), the stumpage market price of $1 \mathrm{~m}^{3}$ of timber is $21 €$ in the with scenario, and increments

\footnotetext{
${ }^{3}$ These authors all pinpoint that there is a periodicity in the response of the trees to attack, which is usually followed by a reduction in radial growth that can last a number of years, during which the trees recover from the defoliation. When the period without attack is as long as the recovery period, tree growth resumes the initial level. This does not happen when the period without attack is shorter than the recovery period, placing the ecosystem equilibrium at serious risk (Lemoine, 1977).
} 
Table 2

The two scenarios for Cost Benefit Analysis

\begin{tabular}{|c|c|c|c|c|c|c|c|}
\hline \multirow[t]{2}{*}{ Item being valued } & \multirow{2}{*}{$\begin{array}{l}\text { Benefit }(+), \\
\text { cost }(-)\end{array}$} & \multirow{2}{*}{$\begin{array}{l}\text { Valuation } \\
\text { technique }\end{array}$} & \multirow{2}{*}{$\begin{array}{l}\text { Physical } \\
\text { indicator }\end{array}$} & \multirow{2}{*}{$\begin{array}{l}\text { Monetary } \\
\text { indicator }\end{array}$} & \multicolumn{3}{|l|}{ Scenario assumptions } \\
\hline & & & & & With & Without & Lit. ref. \\
\hline \multicolumn{8}{|l|}{ Financial Analysis (FA) } \\
\hline Timber revenues & + & Market price & $\begin{array}{l}\text { Yield from } \\
\text { felling }\left(\mathrm{m}^{3}\right)\end{array}$ & $\begin{array}{l}\text { Stumpage } \\
\text { price }\left(€ / \mathrm{m}^{3}\right)\end{array}$ & $\begin{array}{l}\text { Yield from yield } \\
\text { tables; stumpage } \\
\text { price } 21 € / \mathrm{m}^{3}\end{array}$ & $\begin{array}{l}20 \% \text { reduction } \\
\text { in yield and } 12 \% \\
\text { reduction in } \\
\text { stumpage price } \\
\text { in the age } \\
1-20 \text { years }\end{array}$ & $\begin{array}{l}\text { Bouchon and } \\
\text { Toth (1971), } \\
\text { Laurent-Hervouët } \\
\text { (1986) }\end{array}$ \\
\hline Forest management costs & - & Market price & & & $10 € /$ ha & $\begin{array}{l}\text { Remain } \\
\text { unchanged }\end{array}$ & \\
\hline $\begin{array}{l}\text { Pest management } \\
\text { costs }\end{array}$ & - & Market price & & $\begin{array}{l}\text { Cost for Btk } \\
\text { treatment }(€)\end{array}$ & $60 € / \mathrm{ha}$ & None & \\
\hline \multicolumn{8}{|c|}{ Conventional Economic Analysis (CEA) - the same as FA, plus: } \\
\hline Estate value & + & $\begin{array}{l}\text { Capitalisation of } \\
\text { net market flows }\end{array}$ & & $\begin{array}{l}\text { Annuity of } \\
\text { capitalised land } \\
\text { value }(€ / \mathrm{ha})\end{array}$ & & $\begin{array}{l}\text { Decreases by } \\
40 \% \text { because of } \\
\text { timber losses } \\
\text { and financial } \\
\text { factors }\end{array}$ & \\
\hline \multicolumn{8}{|c|}{ Extended Economic Analysis 1(EEA1) - the same as CEA, plus: } \\
\hline Carbon sequestration & + & Market price & $\begin{array}{l}\mathrm{C} \text { sequestered in } \\
\text { forest biomass } \\
\left(t \mathrm{CO}_{2} \mathrm{e}\right)\end{array}$ & $\begin{array}{l}\text { Price of } 1 \\
t \mathrm{CO}_{2} \mathrm{e}(€)\end{array}$ & $\begin{array}{l}\mathrm{C} \text { fixed function of } \\
\text { current increment }{ }^{\mathrm{a}} \text {; } \\
\text { Price } 13 € / t \mathrm{CO}_{2} \mathrm{e}\end{array}$ & $\begin{array}{l}20 \% \text { Reduction } \\
\text { in increment }\end{array}$ & $\begin{array}{l}\text { Croitoru and } \\
\text { Merlo (2005) }\end{array}$ \\
\hline $\begin{array}{l}\text { Risk of dermatitis } \\
\text { for visitors }\end{array}$ & - & $\begin{array}{l}\text { Hospital treatment } \\
\text { cost }\end{array}$ & $\begin{array}{l}\text { Days of } \\
\text { hospital } \\
\text { treatment }\end{array}$ & $\begin{array}{l}\text { Cost of daily } \\
\text { hospital } \\
\text { treatment }(€)\end{array}$ & No-risk & $\begin{array}{l}1 \% \text { risk of } \\
\text { being affected }\end{array}$ & \\
\hline \multicolumn{8}{|c|}{ Extended Economic Analysis 2(EEA2) - the same as EEA1, plus: } \\
\hline Recreation & + & Benefit transfer & $\begin{array}{l}\text { Day visits } \\
\text { per year }\end{array}$ & $\begin{array}{l}\text { Willingness to } \\
\text { pay for } 1 \text { day- } \\
\text { visit }(€)\end{array}$ & $\begin{array}{l}133,000 \text { day-visits/ } \\
\text { year; } 2.75 € / \text { day } \\
\text { visit }\end{array}$ & $\begin{array}{l}20 \% \text { Reduction } \\
\text { in total } \\
\text { recreational } \\
\text { benefit }\end{array}$ & $\begin{array}{l}\text { Carvalho } \\
\text { Mendes (2005) }\end{array}$ \\
\hline
\end{tabular}

${ }^{\text {a }}$ Quantity in $\mathrm{m}^{3}$ of current annual increment $\times 0.6 \mathrm{t} / \mathrm{m}^{3} \times 0.4 t \mathrm{C} / \mathrm{t} \times 3.67=t \mathrm{CO}_{2}$ fixed.

are those reported by specific yield tables. The without scenario assumes timber growth reduced by $20 \%$ and timber market value reduced by $12 \%$ for technological reasons. Management costs are assumed to remain unchanged for the two scenarios, being mainly linked to the area covered by trees and not to their density. As such they do not actually affect the treatment decision. The with scenario of course includes pest management costs.

The corresponding annuity value of land in Conventional Economic Analysis decreases by $40 \%$ in the without scenario as a joint effect of lower timber yields, timber prices and financial factors.

In the next step, Extended Economic Analysis 1 (EEAl), the two new items are carbon sequestration and the social costs linked to dermatitis. The quantity of carbon dioxide fixed by the pine forest (linked to its net annual forest increment) has been multiplied by the price of $1 \mathrm{MT}$ of carbon dioxide equivalent $t \mathrm{CO}_{2} \mathrm{e}{ }^{1}{ }^{1}$ at present estimated as $13 € / t \mathrm{C}$ (Croitoru and Merlo, 2005). A 20\% reduction of forest increment in the without scenario in the attacked period has been attributed to the defoliation effect. The social costs of contact dermatitis are accounted for starting from the annual number of visitors to the pine forests and the estimated risk of coming in contact with the urticating larvae. According to Vega et al. (2003), $9.18 \%$ of a pediatric population of 653 individuals in northwestern Spain has shown a cutaneous reaction but only in four cases there was an important allergy. We thus considered that $1 \%$ of the visitors of the pine forests may require medical treatment in a hospital for one day. The monetary indicator used is the daily cost of hospital treatment in Portugal, 100€/hospital day (WHO, 2007), while this risk is 0 in the with scenario.

Finally, in Extended Economic Analysis 2 (EEA2), the recreational value of the pine forest has been estimated using data published by Carvalho Mendes (2005) for a similar forest site in Portugal. According to this author, the value of 1 dayvisit to forest sites in Portugal is $2.75 €$. The total number of visitors to the pine forests has been assumed as $10 \%$ of the total number of visitors to the area of Setùbal as published by the General Directorate of Tourism. A 20\% reduction in this value has again been assumed in the without scenario.

The choice of the discount rate is another critical issue in forest investment analysis, and this is particularly true for even-aged stands where costs usually occur at the beginning of the rotation, with revenues at the end. In our case-study this is somewhat mitigated by the fact that the forest is composed of different age-classes and by the annual cadence of social benefits. An initial discount rate of $2 \%$ has been assumed for our study, which can be considered rather low. However, its choice follows the suggestions of European 
commentators such as Price (1997), Kula (1984a,b, 1986) and Merlo (1985) who - although with different arguments - are in favour of low discount rates for forest projects with social impacts.

The effects on the CBA results of the most significant assumptions have then been tested by means of a sensitivity analysis.

\section{Results and discussion}

The results of the CBA application are reported in Table 3. Accumulated values for each item of the analysis and NPVs at $2 \%$ are provided for the two scenarios and four CBA steps. Moreover - and more relevant in the context of this study the difference between the with and without alternatives is also reported in the last column. This is the indicator of profitability for pest management versus the no-treatment solution and results will be commented on mainly with reference to it.

In the first step - i.e. Financial Analysis - the NPV difference is negative, meaning unprofitability of pest management for the private forest owner. This result suggests that - under our present assumptions - accumulated net timber revenues from the pest-managed pine woods (around 4.7 million $€$ ) cannot fully compensate for accumulated pest management costs (around 6 million $€$ ). Clearly, the forest owner is better off with a less healthy forest, although this means him giving up part of his revenues: this alternative provides him with a positive NPV, while pest management does not. This actually reflects the present situation, where pest treatment is occasional (see Section 2), thus showing the economic rationale of the behaviour of the forest owner.

The second step of the analysis - Conventional Economic Analysis - looks at pest management profitability also taking

Table 3

Results of Cost Benefit Analysis performed in the Setúbal Peninsula - Net Present Value (NPV) in thousand euro

\begin{tabular}{|c|c|c|c|}
\hline \multirow{2}{*}{$\begin{array}{l}\text { Total benefits }(+) \\
\text { and costs }(-) 000 € \\
\text { Accumulated over } 45 \text { years }\end{array}$} & \multicolumn{3}{|c|}{ Scenarios } \\
\hline & With & Without & $\begin{array}{l}\Delta \text { (With- } \\
\text { without })\end{array}$ \\
\hline \multicolumn{4}{|l|}{ Financial Analysis } \\
\hline $\begin{array}{l}\text { Revenues from timber } \\
\text { production }(+)\end{array}$ & 27,562 & 22,785 & +4777 \\
\hline Forest management costs $(-)$ & 22,266 & 22,266 & 0 \\
\hline Pest management costs $(-)$ & 6044 & 0 & -6044 \\
\hline $\operatorname{NPV}(2 \%)$ & -748 & 519 & -1267 \\
\hline \multicolumn{4}{|c|}{ Conventional Economic Analysis as above \pm : } \\
\hline Estate value $(+)$ & 33,079 & 28,049 & +5030 \\
\hline $\operatorname{NPV}(2 \%)$ & 32,331 & 28,568 & +3763 \\
\hline \multicolumn{4}{|c|}{ Extended Economic Analysis 1 as above \pm : } \\
\hline Carbon sequestration $(+)$ & 9878 & 7902 & +1976 \\
\hline Risk of dermatitis $(-)$ & 0 & 4058 & -4058 \\
\hline NPV $(2 \%)$ & 42,209 & 32,412 & +9797 \\
\hline \multicolumn{4}{|c|}{ Extended Economic Analysis 2 as above \pm : } \\
\hline Recreation $(+)$ & 11,160 & 8928 & +2232 \\
\hline NPV $(2 \%)$ & 53,369 & 41,340 & $+12,029$ \\
\hline
\end{tabular}

into account possible negative variation in timber capital assets due to the attack of processionary moth. The outcome of this further addition is a shift in favour of the with scenario, with a positive NPV difference of around 3.7 million $€$. This indicates that if the no-treatment option is financially more desirable in the short-term, risks of forest decline, when ignored, can threaten forest productivity, which in turn affects market revenues and, eventually, land values. However, uncertainty over future market trends and their effects on timber prices may not be enough to induce forest owners to undertake pest management even in the light of this step of the analysis; this issue will be given further attention in the sensitivity analysis.

Extended Economic Analysis 1 allows comparison of social profitability of pest management by adding off-site market benefits such as the value of the carbon fixed and the cost of medical treatments for those contracting dermatitis. Here, the difference between the NPV of the with and that of the without scenario increases to about 9.7 million $€$ (Table 3), thus indicating that the active management option is certainly worthwhile from a social point of view, where true market benefits are produced by healthy forests, whereas real social costs are avoided. It should be noted that the major part of the net benefit is due to the avoidance of medical costs rather than to carbon fixation, which also occurs, although less efficiently, in the without scenario.

Finally, the social profitability of the with option is reinforced in the Extended Economic Analysis 2, where the inclusion of non-market recreational benefits further increases the with-without NPV difference to more than 12 million $€$. These benefits do not result in a real market transaction and do not therefore produce any real income for the landowner or for the public institutions, however, they express the recreational enjoyment in the Setúbal pine forests by visitors and tourists, whose proxy is represented by their hypothetical willingness to pay for visiting the forest.

As these first results and comments are based on a number of short- and long-term assumptions, a sensitivity analysis has been conducted to test the stability of the results and understand the most critical items of the analysis in terms of effects on the final profitability of the with option in the different CBA steps.

First of all, the effect of the choice of the discount rate is further analysed through the calculation of the Internal Rate of Return (IRR) of the with-without difference which, also in this case, is more relevant for our analysis than the absolute values. For the Conventional Economic Analysis, the Extended Economic Analysis 1 and the Extended Economic Analysis 2, the IRR of the with-without difference is always positive, showing that long-term profitability for the forest owner as well as social profitability are always achieved through the treatment decision, whatever discount rate is chosen for the analysis. Conversely, for the Financial Analysis, a rational producer would invest in the treatment option only with discount rates higher than $77.35 \%$, unlikely to occur in the real world. Therefore, also the results of the Financial Analysis do not seem to be affected by the choice 
of the discount rate unless very wide variations are considered.

The second aspect examined in the sensitivity analysis is the payback period of the two scenarios, which allows us to understand the effect of the choice of the length of time period on which the CBA exercise is based (Fig. 1). The payback period is defined as the length of time needed to give positive NPVs. The outcomes for the Financial Analysis are not reported in Fig. 1, as the with scenario always results as the least favourable whatever time-lapse is chosen. The solid lines in the figure, referring to Conventional Economic Analysis, show that with periods longer than 5 years up to the 11 th year, the without scenario results as being more profitable than the with scenario. However, this outcome is definitively reverted again between the 12th and the 13th year. On the contrary, with Extended Economic Analysis 1 (short-dotted lines) and Extended Economic Analysis 2 (long-dotted lines), the profitability of the with scenario compared to the without scenario is proved regardless of the analysis time-horizon. The payback period ranges from 6 years for EEA1 to 3 years for EAA2. It is interesting to note that the inclusion of social costs and benefits results in an overall divergence of the two trends representing the NPVs each year for the different CBA steps and scenarios (Fig. 1).

Finally, we have tested the effect one by one, of a number of other scenario variables that are likely to change in the future or whose determination is uncertain as already discussed in Section 4. Each of these variables has been tested ceteris paribus, i.e. keeping all the other variables equal to the initial assumption in order to better identify the effect of each variation of the original conditions. Equal variations in with and without scenarios of: value of carbon quotas, quantity of carbon sequestered, value of 1 day-visit and number of visits have been tested with no significant effects. Similarly, increased risk of dermatitis in the without scenario, and smaller recreational losses in the without scenario compared to the with scenario do not alter the results of the main analysis as depicted in Table 3.

Vice versa, the variables which may affect overall profitability of the different CBA steps and the extent to which such effects can occur are reported in Table 4. It should be noted that they only relate to the first two steps of the analysis especially to the Financial Analysis, where, in the base scenario, Btk treatment has proved to be unprofitable - and therefore refer only to the forest owner and not to society as a whole. In the Financial Analysis, profitability reverses in favour of the treating option if $40 \%$ higher timber yields are considered in both the scenarios, and a similar effect is obtained should timber prices increase by $30 \%$. Sensitivity to pest management costs has proved to be more important, as a reduction of around $20 \%$ in the moth treatment cost is enough to induce profitability of the treating option. Other significant shifts can be induced by changes in the assumptions regarding the long-term consequences of the pest attack on forest productivity. In the original without scenario, based on the existing literature, we have assumed a $20 \%$ yield reduction in non-treated pine forests and a $12 \%$ reduction in timber prices. However, if these losses increase to $40 \%$ of yields or $22 \%$ in prices the treating option becomes worthwhile. On the other hand, if the decrease of land values for the nontreated forest was only about $10 \%$ instead of $40 \%$ as originally assumed in the CEA, CBA results would be in favour of the without scenario. This information casts further light on the crucial points of the whole analysis, especially in terms of possible forest management strategies.

\section{Conclusions}

We believe that the first objective of the paper - i.e. to attempt at outlining a framework for analyses of pest management strategies in wide social context - has been achieved, although not fully. The progressive assessment and inclusion of the cost and benefits of the investments in order to identify the social optimum is acceptable because the overall project objectives - economic, social and environmental - are to a large extent compatible and not competitive, therefore additive. However, open questions remain, especially on the methods used for the evaluation of the non-market benefits, as even now largely debated in the environmental economics literature, where Contingent Valuation is not unanimously

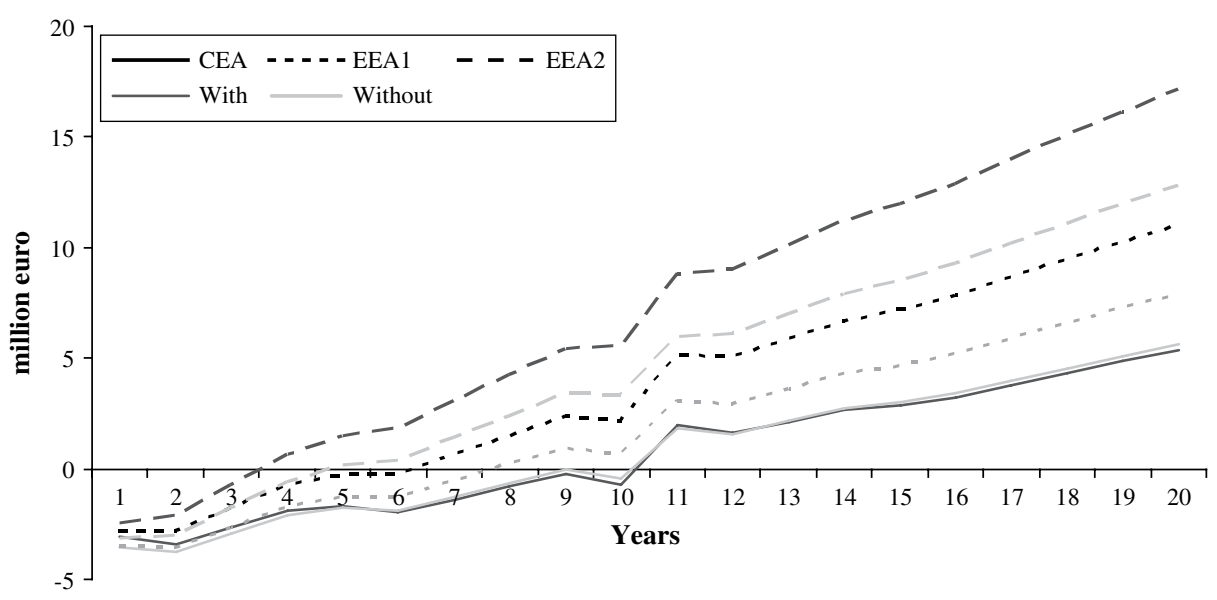

Fig. 1. Payback period for the different Cost Benefit Analysis steps and scenarios in the Setúbal Peninsula - discounted cash-flows, million $€$. 
Table 4

Significant results of sensitivity analysis of different assumptions for the Cost Benefit Analysis steps and scenarios, each assumption singularly, ceteris paribus

\begin{tabular}{|c|c|}
\hline & $\begin{array}{l}\text { Increase }(+) \text { or decrease } \\
(-) \text { inducing reversion of } \\
\text { profitability }(\%)\end{array}$ \\
\hline \multicolumn{2}{|l|}{ Financial Analysis } \\
\hline $\begin{array}{l}\text { Timber yields in both with and without } \\
\text { scenarios }\end{array}$ & +40 \\
\hline $\begin{array}{l}\text { Timber prices in both with and without } \\
\text { scenarios }\end{array}$ & +30 \\
\hline Pest management costs in the with scenario & -20 to -21 \\
\hline $\begin{array}{l}\text { Timber yields in the without scenario } \\
\text { compared to the with scenario }\end{array}$ & -40 \\
\hline $\begin{array}{l}\text { Timber prices in the without scenario } \\
\text { compared to the with scenario }\end{array}$ & -22 \\
\hline \multicolumn{2}{|l|}{ Conventional Economic Analysis } \\
\hline $\begin{array}{l}\text { Estate value in the without scenario } \\
\text { compared to the with scenario }\end{array}$ & -10 to -11 \\
\hline
\end{tabular}

accepted amongst commentators and has its detractors (Diamond and Hausman, 1994) - for a critical review, see, e.g. Boyle and Bergstrom (1999). Moreover, we have used Benefit Transfer technique in its simplest option, i.e. by transferring unit values, however, caution must be used in this, and reference to function transfer is now regarded as a more robust alternative (Spash and Vatn, 2006).

Besides the methodological pitfalls, other sources of mistakes to be encountered in the empirical applications especially in the two Extended Economic Analysis - may include possible omissions of impacts, double counting, different spatial scales of the value components and related aggregation problems (Whitby, in press).

All these issues, together with the lack of previous studies on this subject, have made the evaluation process more difficult and have stressed the need to bridge the gap between entomological and economic research, in particular in understanding the long-term effects of pests, a key factor as yet not fully determined.

Within these methodological limitations, the different costs and benefits involved in the Setúbal case-study have been identified and reasonable estimates for them have been provided: in this, we trust that the second objective of the paper was accomplished. One of the most important outcomes of the empirical application has been highlighting that the profitability threshold lies beyond the strictly private profitmaximisation function. Indeed, the results show that pest management costs outweigh market revenues, making processionary moth control unprofitable for the forest owner in the short-term. Only in the long-term, and if present conditions are assumed to remain constant, pest management turns profitable when the forest owner takes into account maintenance of the capital value of his forest land. A social profit is instead gained by practicing processionary moth management, thus avoiding possible loss of environmental-recreational values and social costs caused by the health risk to humans and domestic animals.
Possible policy implications originating from these results entail - in the short-term - considering the need to provide public financial support to the private landowner for pest management. The use of taxpayers' money to pay for pest control which would not otherwise be done can be justified by the possible loss of benefits such as carbon sequestration, recreation, and the risks to public health which affect the community at large. Financial support could be provided directly by partially meeting treatment costs, or indirectly by supporting forms of pooling of forest owners so as to achieve returns to scale in Btk aerial spraying. This issue seems particularly important in the light of the results of the sensitivity analysis, which has shown that the profitability threshold can be reached if pest management costs are reduced by $20 \%$. The Community Rural Development Policy presently under discussion for the programming period 2007-2013 might be a good occasion to consider these arguments.

\section{Acknowledgements}

This work has been financed by the Commission of the European Communities 'Quality of Life and Management of Living Resources' specific RTD programme, Contract QLK5-CT-2002-00852 'PROMOTH: Global change and pine processionary moth: a new challenge for integrated pest management'. The study does not necessarily reflect the Commission's views and in no way anticipates the Commission's future policy on the matter. Special thanks to the AFLOP Association of Forest Owners of the Setúbal Peninsula and the Portuguese Forest Services for providing the data on costs and revenues of pine forests. The authors are grateful to three anonymous reviewers for their valuable comments and suggestions for improving an earlier version of the paper. The usual disclaimer applies.

\section{Appendix. Supplementary data}

Supplementary data associated with this article can be found, in the online version, at doi:10.1016/j.jenvman.2008. 01.007.

\section{References}

Bangsund, A., Leistritz, F.L., Leitch, J.A., 1999. Assessing economic impact of biological control of weeds: the case of leafy spurge in the Northern Great Plains of the United States. Journal of Environmental Management 56, 35-43.

Bateman, J.J., Willis, K.G., 1999. Valuing Environmental Preferences Theory and Practice of the Contingent Valuation Method in the US, EU and Developing Countries. University Press, Oxford.

Bouchon, J., Toth, J., 1971. Étude préliminaire sur les pertes de production des pinèdes soumises aux attaques de la processionaire du pin Thaumetopoea pityocampa Schiff. Annales Sciences Forestières 28, 323-340.

Boyle, K.J., Bergstrom, J.C., 1999. Doubt, doubts and doubtsers: the genesis of a new research agenda? In: Bateman, I.J., Willis, K.G. (Eds.), Valuing Environmental Preferences - Theory and Practice of the Contingent Valuation Method in the US, EU, and Developing Countries. Oxford University Press, Oxford, pp. 183-206. 
Brethour, C., Weersink, A., 2001. An economic evaluation of the environmental benefits from pesticide reduction. Agricultural Economics 25, 219-226.

Carus, S., 2004. Impact of defoliation by the pine processionary moth (Thaumetopoea pityocampa) on radial, height and volume growth of Calabrian pine (Pinus brutia) trees in Turkey. Phytoparasitica 32, 459-469.

Carvalho Mendes, A., 2005. Portugal. In: Croitoru, L., Merlo, M. (Eds.), Mediterranean Forests and People: towards the Total Economic Value. CABI Printing, Wallingford, pp. 331-352.

Cesaro, L., Cistulli, V., Merlo, M., Pettenella, D., 1998. A step-wise procedure to costs and benefits analysis (CBA) of forestry and soil conservation investments in the Mediterranean watersheds. In: Tikkanen, I., Pajari, B. (Eds.), Future Forest Policies in Europe. Balancing Economic and Ecological Demands EFI Proceedings 22, Joensuu, pp. 149-167.

Cornejo, J.F., 1998. Environmental and economic consequences of technology adoption: IPM in viticulture. Agricultural Economics 18, 145-155.

Cuyno, L.C.M., Norton, G., Rola, A., 2001. Economic analysis of environmental benefits of integrated pest management: a Philippine case study. Agricultural Economics 25, 227-233.

Croitoru, L., Merlo, M., 2005. Mediterranean Forests and People: towards the Total Economic Value. CABI Printing, Wallingford.

Demolin, G., Martin, J.-C., 1998. Lutte contre la Processionnaire du pin. Efficacité et persistance d'action de deux formulations a base de Bacillus thuringiensis. Phytoma 507, 11-14.

Diamond, P.A., Hausman, J.A., 1994. Contingent valuation: is some number better than no number? Journal of Economic Perspectives 8, 45-64.

Fleischer, F., Jungbluth, F., Waibel, H., Zadoks, J.C., 1999. A Field Practitioner's Guide to Economic Evaluation of IPM. In: Pesticide Policy Project Publication Series, No. 9. Institute for Economics in Horticulture, University of Hannover in cooperation with Food and Agricultural Organization of the United Nations.

Fuentes Aparicio, V., de Barrio Fernandez, M., Rubio Sotés, M., Rodríguez Paredes, A., Molero Marítnez, M.I., Zapatero Remón, L., Bartolomé Zavala, B., 2004. Nonoccupational allergy caused by the pine processionary caterpillar Thaumetopoea pityocampa. Allergologie et Immunopathologie 32, 69-75.

Gregersen, H., Contreras, A., 1979. Economic analysis of forestry projects impacts. FAO Forestry Paper, No. 17. FAO, Rome.

Hanley, N., Wright, R.E., Alvarez-Farizo, B., 2006. Estimating the economic value of improvements in river ecology using choice experiments: an application to the water framework directive. Journal of Environmental Management 78, 183-193.

Hódar, J.A., Castro, J., Zamora, R., 2003. Pine processionary caterpillar Thaumetopoea pityocampa as a new threat for relict Mediterranean Scots pine forests under climatic warming. Biological Conservation 110, 123-129.

IETA, 2005. State and Trends of the Carbon Market 2005. International Emissions Trading Association, Washington, DC.

Jetter, K., Paine, T.D., 2003. Consumer preferences and willingness to pay for biological control in the urban landscape. Biological Control 30, 312-322.

Kanat, M., Alma, M.H., Sivrikaya, F., 2005. Effect of defoliation by Thaumetopoea pityocampa (Den. \& Schiff.) (Lepidoptera: Thaumetopoeidae) on annual diameter increment of Pinus brutia Ten. in Turkey. Annals of Forest Science 62, 91-94.

Kula, E., 1984a. Discount factors for public sector investments using the sum of discounted consumption flows method - estimates for the U.K. Environment and Planning A 16, 689-694.

Kula, E., 1984b. Justice and efficiency with the sum of discounted consumption flows method. Environment and Planning A 16, 835-838.

Kula, E., 1986. The developing framework for the economic evaluation of forestry in the United Kingdom. Journal of Agricultural Economics 37, 365-376.
Larsson, S., 1983. Effects of artificial defoliation on stem growth in Salix smithiana grown under intensive culture. Acta Oecologica, Oecologia Applicata 4, 343-349.

Laurent-Hervouët, N., 1986. Mesure des pertes de croissance radiale sur quelques espèces de Pinus dues a deux defoliateurs forestiers. I - Cas de la processionaire du pin en région méditerranéenne. Annales Sciences Forestières 43, 239-262.

Lemoine, B., 1977. Contribution à la mesure des pertes de production causeés par la chenille processionnaire (Thaumetopoea pityocampa Schiff.) au Pin Maritime dans les Landes de Gascogne. Annales Sciences Forestières 34, 205-214.

Little, I.M.D., Mirrlees, J.A., 1974. Project Appraisal and Planning for Developing Countries. Heinemann Educational, London.

Lutz, E., Munasinghe, M., 1994. Integration of environmental concerns into economic analyses of project and policies in an operational context. Ecological Economics 10, 37-46.

Masutti, L., Battisti, A., 1990. Thaumetopoea pityocampa (Den. \& Schiff.) in Italy. Bionomics and perspectives of integrated control. Journal of Applied Entomology 110, 229-234.

Mattson, W.J., Niemela, P., Rousi, M., 1996. Dynamics of Forest Herbivory: Quest for Pattern and Principle. General Technical Report North Central Forest Experiment Station, USDA, Forest Service No. NC-183, p. 286.

Merlo, M., 1985. Alcune osservazioni sui contenuti ed i metodi dell'estimo forestale, CeSET, Quaderno n. 2, Tip. Lorenzini, Bologna.

Merlo, M., Jöbstl, H., 1999. Incorporation of non-market outputs into forestry reporting and accounting. In: Roper, C.S., Park, A. (Eds.), The Living Forest-Non Market Benefits of Forestry. The Stationery Office, London, pp. 341-372.

Mullen, J.D., Norton, G.W., Reaves, D.W., 1997. Economic analysis of environmental benefits of integrated pest management. Journal of Agricultural and Applied Economics 29, 243-253.

Price, C., 1997. Twenty-five years of forestry cost-benefit analysis in Britain. Forestry 70, 171-189.

Saphores, J.D., Shogren, J.F., 2005. Managing exotic pests under uncertainty: optimal control actions and bioeconomic investigations. Ecological Economics 52, 327-339.

Simberloff, D., 2001. Management of boreal forest biodiversity - a view from the outside. Scandinavian Journal of Forest Research 3, 105-118.

Spash, C.L., Vatn, A., 2006. Transferring environmental value estimates: issues and alternatives. Ecological Economics 60, 379-388.

Vega, J.M., Moneo, I., Armentia, A., Vega, J., de la Fuente, R., Fernandez, A., 2000. Pine processionary caterpillar as a new cause of immunologic contact urticaria. Contact Dermatitis 43, 129-132.

Vega, M.L., Vega, J., Vega, J.M., Moneo, I., Sanchez, E., Miranda, A., 2003. Cutaneous reaction to pine processionary caterpillar (Thaumetopoea pityocampa) in pediatric population. Pediatric Allergy and Immunology $14,482-486$.

Vega, J.S., Vega, J.M., Moneo, I., Armentia, A., Caballero, M.L., Miranda, A., 2004. Occupational immunologic contact urticaria from pine processionary caterpillar (Thaumetopoea pityocampa):experience in 30 cases. Contact Dermatitis 50, 60-64.

Wainhouse, D., 2005. Ecological Methods in Forest Pest Management. Oxford University Press, Oxford

Whitby, M., The Struggle to Evaluate Forestry Policy in the UK. In: International Conference on Multifunctional Agriculture and Forestry Policies, Methods and Case Studies. Padova, Italy, 28-30 April 2005, in press.

WHO, 2007. Estimates of Unit Costs for Patient Services for Portugal. Available from: http://www.who.int/choice/country/prt/cost/en/index.html. 